\title{
DENTAL CARIES AND DENTAL FLUOROSIS IN 7-12-YEAR- OLD SCHOOLCHILDREN IN CATALÃO, GOIÁS, BRAZIL
}

\author{
CÁRIE E FLUOROSE DENTÁRIA EM ESCOLARES DE 7 A 12 ANOS DE IDADE \\ EM CATALÃO, GOIÁS, BRASIL
}

Priscila Ariede Petinuci BARDAL ${ }^{1}$, Kelly Polido Kaneshiro OLYMPIO ${ }^{1}$, Marília Afonso Rabelo BUZALAF ${ }^{2}$, José Roberto de Magalhães BASTOS ${ }^{3}$

\begin{abstract}
1- DDS, MSc, Graduate student (Master degree), Departament of Community Health, Bauru Dental School, University of São Paulo, Brazil.
2- DDS, MSc, PhD, Associate Professor, Departament of Biological Sciences, Bauru Dental School, University of São Paulo, Brazil.

3- DDS, MSc, PhD, Associate Professor, Departament of Community Health, Bauru Dental School, University of São Paulo, Brazil.
\end{abstract}

Corresponding address: Marília Afonso Rabelo Buzalaf - Al. Octávio Pinheiro Brisolla, 9-75 - Bauru-SP, Brazil - Cep.:17012-901

Phone: (OXX14) 3235-8246; Fax: (OXX14) 3226-2076- E-mail: mbuzalaf@fob.usp.br

Received: January 20, 2004 - Modification: March 31, 2004 - Accepted: June 07, 2004

\begin{abstract}
I

ntroduction: Over the last two decades, the prevalence of dental caries in children has decreased and the prevalence of dental fluorosis has increased. Knowledge on the epidemiologic conditions of a population is fundamental for the planning of health programs.Objectives: To determine the prevalence of dental caries and dental fluorosis among schoolchildren, in Catalão, Goiás, Brazil. Methods: A random sample of 432 schoolchildren aged 7-12-years old was obtained. WHO (1997) criteria for dental caries and fluorosis diagnosis were used. Results: The DMFT indexes were 0.97; 1.20; 1.80; 1.62; 2.40 and 2.51 for 7 , 8, 9, 10, 11 and 12 years old, respectively. Analysis of dental fluorosis for the same ages presented higher prevalence at 12 years old and for the female gender. The percentage of questionable dental fluorosis (Dean's classification) was 34.0\%. Only 3\% of the sample presented dental fluorosis with scores very mild, mild and moderate. Conclusions: The prevalence of caries in schoolchildren of Catalão, Goiás, Brazil, was low. In average, private schools showed better results than public schools; however, all schools presented a low DMFT index. In this study, dental fluorosis is not a public health problem and has not damaged dental esthetics.

Uniterms: Epidemiology; School health; Oral health surveys; Oral diagnosis; Dental caries; Dental fluorosis.
\end{abstract}

\section{RESUMO}

$I_{\text {n }}$ Lén aumentado. Para se planejar programas de saúde é fundamental conhecer o perfil epidemiológico das populações. Objetivos: Determinar a prevalência de cárie dentária e fluorose dentária em escolares do município de Catalão, Goiás, Brasil. Métodos: A amostra randomizada foi composta por 432 escolares de 7 a 12 anos de idade. Os critérios utilizados para determinar a prevalência de cárie dentária e fluorose seguiram a metodologia proposta pela OMS, 1997. Resultados: Os valores do Índice CPOD foram de 0,$97 ; 1,20 ; 1,80 ; 1,62 ; 2,40$ e 2,51 para as idades de 7, 8, 9, 10, 11 e 12 anos, respectivamente. Considerando o diagnóstico de fluorose dentária para as mesmas idades, houve maior prevalência nos estudantes de 12 anos de idade e no gênero feminino. A porcentagem de fluorose dentária questionável (classificação de Dean) foi de 34,0\%. Somente 3,0\% da amostra total, apresentou fluorose dentária nos escores muito leve, leve e moderado. Conclusões: A prevalência de cárie dentária em escolares de Catalão, Goiás, Brasil foi baixa. As escolas particulares mostraram melhores resultados que as escolas públicas, entretanto, em todas elas se verificou baixos valores do Índice CPOD. Neste estudo, a fluorose dentária não tem causado problemas à estética dental e não se caracterizou em um problema de Saúde Pública.

Unitermos: Epidemiologia; Saúde escolar; Levantamentos de saúde bucal; Cárie dentária; Fluorose dentária. 


\section{INTRODUCTION}

In most industrialized countries, the prevalence of dental caries in children has decreased over the last two decades ${ }^{12,20}$. The joint FDI/WHO working group for Oral Health Research and Epidemiology indicated that the factor common to all countries with substantial reductions in caries prevalence was fluoride, either as fluoridated water or in toothpaste ${ }^{20}$. In addition to the considerable benefits, the use of fluoride increases the risk of dental fluorosis, a condition that has been observed in both fluoridated and non-fluoridated populations $6,8,9,19$.

In Brazil, water fluoridation started in 1953, in Baixo Guandu, Espírito Santo state, but only in 1974 a Federal Law regulated its implementation ${ }^{11}$.

Catalão is a Brazilian city with 64,281 inhabitants, located at the south of Goiás state. Water fluoridation in Catalão started in 1991 and 0.7 ppm fluoride (as hydrofluosilicic acid) was added to the public water supply. The aim of this study was to describe the prevalence of dental caries and dental fluorosis, among schoolchildren aged 7-12-years old and compare the results found for private and public schools, based in a cross-sectional study performed in 2001.

\section{METHODS}

\section{Population and sampling}

The research was a cross-sectional study that described the prevalence of dental caries and dental fluorosis among schoolchildren aged 7-12-years old and compared the results found for private and public schools. The probabilistic and stratified sample according to age, gender, kind of school and city's districts resulted of a plane in which the sample units were public and private schools. In 2001, 432 children from 6 schools (336 from public schools and 96 from private schools) were examined. The schoolchildren were randomly selected. These urban elementary schools were chosen because they represent quite well the city's population regarding the socioeconomic status. The sample size was calculated based in the WHO guidelines ${ }^{23}$. The reference system for the sampling plane was the records of schools from Catalão, supplied by the Education Regional Department and City Hall. This research was approved by the Ethics Committee of Bauru Dental School, University of São Paulo.

\section{Clinical examinations}

One dentist previously calibrated carried out the clinical examinations. The examinations were made under natural light, using a mirror, a Community Periodontal Index (CPI) probe, as indicated by the WHO, and gauze for drying the teeth before accomplishment of the dental fluorosis test. CPI probes ("ball point”) are used especially in epidemiologic surveys to remove debris over tooth, thus improving the visualization $^{23}$. The components of the DMFT index have been defined as follows: $\mathrm{D}=$ Tooth requiring treatment because of caries, lost or fractured filling; $\mathrm{M}=$ Tooth missed because of caries, and F = Filled or crowned tooth, no need of treatment. The total number of caries-free (CF) schoolchildren was also recorded. All present teeth in these children were examined. Dental fluorosis was assessed by the Dean's classification system ${ }^{7}$. According to this method, each individual receives a score corresponding to the clinical appearance of the two teeth most affected in the mouth. If the two teeth were not equally affected, the classification is determined by the less involved tooth. Criteria have been defined as follows: normal, questionable, very mild, mild, moderate and severe ${ }^{23}$.

The Kappa test was performed, presenting satisfactory results in the agreement tests (Kappa 0.95 for dental fluorosis and 0.97 for dental condition). Tables with absolute and relative frequencies of all data analyzed were made for descriptive statistics.

\section{RESULTS}

Table 1 shows the mean DMFT, standard deviations and percentage of 7-12-year-old caries-free (CF) schoolchildren in Catalão. The DMFT index at 12 years old was 2.51, which is considered by the WHO as low caries prevalence. The smallest prevalence of CF students was seen among 9-yearolds.

Table 2 shows the mean DMFT, standard deviations and percentage of 7-12-year-old CF schoolchildren according to the kind of school. Private schools presented lower values of DMFT index, while public schools presented a higher DMFT index and lower percentages of CF.

Tables 3 and 4 show, respectively, dental fluorosis prevalence (\%) according to the kind of school and dental fluorosis prevalence (\%) according to age and gender. Dental fluorosis increased with age, despite the low prevalence. The students of female gender showed a high percentage of this phenomenon. The prevalence of severe score in this population was $0 \%$.

\section{DISCUSSION}

This is the first epidemiological study regarding the oral health status in Catalão and thus can be considered as baseline data. The results indicate a low dental caries and fluorosis prevalence in the population examined. In some Brazilian cities, the decline in dental caries had already been documented $^{8}$. This decline has been largely attributed to the public water fluoridation, up to the 70 's ${ }^{22}$ and to the widespread use of fluoridated toothpastes, which began at the late 80 's ${ }^{20}$. The use of fluoridated toothpastes in Brazil was intensified in 1989, when the Ministry of Health ${ }^{3}$ regulated the addition of fluoride to toothpastes (not obligatory). An increase of $45 \%$ in the consumption of toothpaste was seen in Brazil during the last 15 years. The amount of toothpaste used in Brazil is $1.4 \mathrm{~g}$ per day ${ }^{5}$. 
Public water fluoridation in Catalão was started in 1991. Since 1991, fluoridation of the public water supply is being implemented throughout the city, except for the Castello Branco district, where water from an artesian well is used. The standardized dosage in the city, according to SANEAGO - the company responsible for administration of the Water Department - is 0.7ppm fluoride (as hydrofluorosilicic acid).

Considering the interior of the Goiás State, Freire, et al. ${ }^{10}$ published the results of an epidemiological survey carried out in 1994. Students aged 6-12 years old of public schools of some cities (Aparecida de Goiânia, Goiânia, Catalão, Goianésia, Inhumas, Jataí, Quirinópolis, Senador Canedo, Trindade and Uruaçu) were studied. The mean DMFT index of this region ranged between 0.41 at 6 years old and 5.19 at 12 years old. Only $4.4 \%$ of the students were free of caries at 12 years of age. Specifically, the city of Goiânia, capital of Goiás State, presented a DMTF index of 4.59 at 12 years old.

The DMFT index in Catalão increased with age, while the dmft index decreased. These values can be compared to
Sorocaba, a city of São Paulo state, where the DMFT index at $7-10$ and 12 years was $0.5,0.8,1.2,1.6$ and 2.6, respectively. Regarding the dmft index, the values were 3.8, 3.3, 2.5, 1.4 and 0.3 , respectively, for the same ages ${ }^{6}$.

Considering only the age of 12 , Catalão presented a DMFT index of 2.51, showing a low prevalence of dental caries. This condition of dental caries can be compared to the study done by Almeida, et al. ${ }^{1}$ (2003) in Portugal. In that country, the DMFT index for 12-year-old schoolchildren was 1.5. However, in Distrito Federal, Mexico ${ }^{17}$, for the same age, the DMFT index was 3.11.

The epidemiologic survey in Catalão showed that private schools presented lower values of DMFT index than public schools. Some authors ${ }^{1,13}$ have shown similar results, using the kind of school as an indicator of socioeconomic conditions in urban environments. In addition, gender had minor effects on the caries experience index ${ }^{1}$.

In Catalão, there are not preventive programs directed to schoolchildren. In this sense, fluoridation of the public water supply and the use of fluoride toothpastes are very

TABLE 1- Mean DMFT, mean dmft (standard deviations) according to age and gender and percentage of 7-12-year-old caries-free (CF) schoolchildren in Catalão, 2001

\begin{tabular}{lllll}
\hline Age and Gender & $\mathbf{n}$ & $\begin{array}{c}\text { DMFT } \\
\text { Mean (sd) }\end{array}$ & $\begin{array}{c}\text { dmft } \\
\text { Mean (sd) }\end{array}$ & $\begin{array}{c}\text { CF } \\
\text { Mean (\%) }\end{array}$ \\
\hline 7 & 72 & $0.97(1.55)$ & $2.79(2.98)$ & 20.83 \\
8 & 72 & $1.20(1.39)$ & $3.50(3.25)$ & 16.67 \\
9 & 72 & $1.80(1.69)$ & $3.09(2.60)$ & 8.30 \\
10 & 72 & $1.62(1.56)$ & $1.73(1.89)$ & 12.50 \\
11 & 72 & $2.40(1.83)$ & $0.77(1.18)$ & 22.22 \\
12 & 72 & $2.51(2.32)$ & $0.31(0.85)$ & 16.20 \\
Male & 216 & $1.65(1.82)$ & $2.20(2.73)$ & 15.28 \\
Female & 216 & $1.85(1.84)$ & $1.86(2.42)$ & 15.74 \\
Mean & 432 & $1.75(1.83)$ & $2.03(2.58)$ & \\
\hline
\end{tabular}

TABLE 2- Mean DMFT, mean dmft (standard deviations) and percentage of 7-12-year-old caries-free (CF) schoolchildren by school in Catalão, 2001

\begin{tabular}{|c|c|c|c|c|}
\hline School & $\mathbf{n}$ & $\begin{array}{c}\text { DMFT } \\
\text { Mean (sd) }\end{array}$ & $\begin{array}{l}\text { dmft } \\
\text { Mean (sd) }\end{array}$ & $\begin{array}{l}\text { CF } \\
\text { Mean (\%) }\end{array}$ \\
\hline 1-private & 48 & 1.25 (1.63) & $1.20(1.59)$ & 22.92 \\
\hline 2-private & 48 & $1.29(1.71)$ & $1.85(2.27)$ & 31.25 \\
\hline 3-state & 84 & $1.13(1.60)$ & $1.98(2.71)$ & 21.43 \\
\hline 4- state & 84 & $1.83(1.76)$ & $1.54(2.10)$ & 14.29 \\
\hline 5- state & 84 & $2.20(1.84)$ & $2.33(2.56)$ & 8.33 \\
\hline 6-municipal & 84 & $2.40(1.97)$ & $2.85(3.25)$ & 5.95 \\
\hline Private mean & 96 & $1.27(1.66)$ & $1.53(1.98)$ & 27.08 \\
\hline Public mean & 336 & $1.89(1.85)$ & $2.18(2.72)$ & 12.50 \\
\hline General mean & 432 & 1.75 (1.83) & $2.03(2.58)$ & 15.74 \\
\hline
\end{tabular}


important measures for prevention of dental caries. In addition, it should be emphasized that all these explanations are speculative, because they were not analyzed with statistical data or were only based on ecological studies ${ }^{15}$.

In order to reach the WHO goal for 2010, which is a $\mathrm{DMFT} \leq 1$, it is necessary to rigorously monitor public water fluoridation in the city. Ideally, other institutions, besides the City Water Department, should perform the quality control. Supervised toothbrushing should be implemented in kindergartens and elementary schools as a municipal law, because fluoridated toothpastes are a cost-effective and feasible method of fluoride delivery. In addition, weekly rinses with $0.2 \%$ sodium fluoride in schools must go on until the DMFT at 12 years-old is $\leq 1$. Then, the caries prevalence at proximal surfaces must be followed for 3 years. If it does not increase, the rinses could be discontinued. According to Seppä $^{22}$ (2001) a shift from population-based prevention to a high-risk strategy has been promoted in countries where caries is strongly polarized. In Finland, however, an intensive preventive program targeted to high-risk individuals had little effect on caries increment, which suggests that the utility of a high-risk strategy is questionable. The relative effects of population-based methods have also decreased during the last decades, but water fluoridation is still effective in countries with a lower level of basic prevention and a less homogenous social structure, like Brazil. From the standpoint of cost-effectiveness, the use of professionally applied fluoride gels has been questioned in children with a low caries rate, and the same is probably true for fluoride varnishes. In countries with a high caries rate, low level of basic prevention and unorganized dental care system, any preventive program seems to be effective.

It is also important that a strong program in dental health education is implemented. The focus should be centralized on the families, with the aid of associations, churches and clubs. This way, when the whole family is involved, the knowledge is more easily transferred to the daily life.

Dental fluorosis is a hypoplasia or hypomineralization of tooth enamel or dentin produced by the chronic ingestion of excessive amounts of fluoride during the period when teeth are developing.

Although both primary and permanent teeth may be affected by fluorosis, under uniform conditions of fluoride availability, fluorosis tends to be greater in permanent teeth than in primary teeth. This disparity may be related to the fact that the period of enamel formation for primary teeth is shorter than for permanent teeth, and that the enamel of primary teeth is thinner and has greater opacity than that of permanent teeth, which makes the detection of fluorosis more difficult ${ }^{14}$.

Campos, et al. ${ }^{4}$ (1998) performed a survey to verify the prevalence of dental fluorosis in students of Brasilia, Federal

TABLE 3- Dental fluorosis prevalence (\%) according to age and gender, in Catalão, 2001

\begin{tabular}{lllllll}
\hline Age and gender & $\mathbf{n}$ & Normal & Questionable & Very Mild & Mild & Moderate \\
\hline 7 & 72 & 63.89 & 34.72 & 0.00 & 1.39 & 0.00 \\
8 & 72 & 62.50 & 34.72 & 1.39 & 0.00 & 1.39 \\
9 & 72 & 80.56 & 19.44 & 0.00 & 0.00 & 0.00 \\
10 & 72 & 61.11 & 36.11 & 1.39 & 1.39 & 0.00 \\
11 & 72 & 59.72 & 34.72 & 4.17 & 1.39 & 0.00 \\
12 & 72 & 50.00 & 44.44 & 5.56 & 0.00 & 0.00 \\
Male & 216 & 65.28 & 33.33 & 0.93 & 0.46 & 0.00 \\
Female & 216 & 60.65 & 34.72 & 3.24 & 0.93 & 0.46 \\
\hline
\end{tabular}

TABLE 4- Dental fluorosis prevalence (\%) according to kind of school, in Catalão, 2001

\begin{tabular}{lllllll}
\hline School & $\mathbf{n}$ & Normal & Questionable & Very Mild & Mild & Moderate \\
\hline 1-private & 48 & 52.08 & 45.83 & 0.00 & 2.08 & 0.00 \\
2-private & 48 & 68.75 & 31.25 & 0.00 & 0.00 & 0.00 \\
3-state & 84 & 50.00 & 42.86 & 5.95 & 1.19 & 0.00 \\
4-state & 84 & 52.38 & 44.05 & 3.57 & 0.00 & 0.00 \\
5-state & 84 & 83.33 & 14.29 & 0.00 & 1.19 & 1.19 \\
6-municipal & 84 & 69.05 & 29.76 & 1.19 & 0.00 & 0.00 \\
Private mean & 96 & 60.42 & 38.54 & 0.00 & 1.04 & 0.00 \\
Public mean & 336 & 63.69 & 32.74 & 2.68 & 0.60 & 0.30 \\
\hline
\end{tabular}


District, a community with $0.8 \mathrm{ppm}$ of fluoride in the public water supply. A total of 833 children of both genders were examined, with ages ranging between 8 and 12 years, all residents in Brasília since birth. The percentage of children without dental fluorosis was high (85.36\%), while $14.64 \%$ of the children presented scores of dental fluorosis between very mild and moderate. The city of Catalão showed only $3.00 \%$ of dental fluorosis when the category "questionable" was excluded, showing a low prevalence, especially when compared to other studies. In Sorocaba ${ }^{6}$, São Paulo, the fluorosis prevalence in 7-12-year-old schoolchildren was 87.3\% (normal and questionable), 8.2\% (very mild), 2.2\% (mild), $0.8 \%$ (moderate) and $0.1 \%$ (severe). At the age of 12 , Catalão presented $5.56 \%$ (very mild) and values $0.00 \%$ to mild, moderate and severe. In Portugal ${ }^{1}$, the prevalence was $21.1 \%$ (questionable), $11.0 \%$ (very mild) and 2.5\% (moderate). Curitiba ${ }^{19}$, a southern city of Brazil, had a fluorosis prevalence of $23.0 \%$ at 12 years old, including scores very mild, mild, moderate and severe of Dean's classification. All these studies ${ }^{1,6,19}$, including the present, concluded that dental fluorosis does not constitute a problem with wide dimensions in Public Health.

Despite the low prevalence, the students of female gender in Catalão showed a high percentage of fluorosis: 3.24\% (very mild), $0.93 \%$ (mild) and $0.46 \%$ (moderate). In Italy ${ }^{2}, 12$ year-old students of female gender presented $5.70 \%$ (very mild), 0.40 (mild), $0.00 \%$ (moderate) and $0.40 \%$ (severe). The higher prevalence in this specific group may be due to possible exposure of these children to others sources of fluoride $^{6}$, which was not investigated in study. A crosssectional study carried out in Belo Horizonte ${ }^{16}$, state of Minas Gerais, Brazil, reported that the variable gender did not affect the occurrence of dental fluorosis.

Fejerskov, et al. ${ }^{5}$ (1994) in a literature review, reported an increase in dental fluorosis with age. This fact was observed in students of Catalão, but most students did not show dental fluorosis, which is in agreement with the studies of Riopdan and Banks ${ }^{13}$ (1991). These authors found scores very mild and mild of dental fluorosis in a population living in a region with $1 \mathrm{ppm}$ of fluoride in water of supply, which is similar to our results. This reinforces the safety and importance of adequate use of fluoridated water and fluoridated dentifrices for caries prevention.

\section{CONCLUSIONS}

The prevalence of caries of schoolchildren in Catalão, Goiás, Brazil, was low. In average, private schools showed better results than public schools; however, all schools presented a low DMFT index. In this study, dental fluorosis does not constitute a Public Health problem and has not damaged dental esthetics.

\section{REFERENCES}

1- Almeida CM, Petersen PE, André SJ et al. Changing oral health status of 6-and 12-year-old schoolchildren in Portugal. Community Dent Oral Epidemiol 2003; 20(4):211-6.

2- Angelillo IF, Torre I, Nobile CGA, Villari P. Caries and fluorosis prevalence in communities with different concentrations of fluoride in the water. Caries Res 1999; 33(2):114-22.

3- Brasil. Ministério da Saúde. Secretaria Nacional de Vigilância Sanitária. Portaria no. 22, de 20 de dezembro de 1989. Diário Oficial da União, Brasília, 1989; 241, 22 dez.

4- Campos DL, Farias DG, Toledo OA, Bezerra AC. Prevalence of dental fluorosis in school children of Brasília - Federal District. Prevalência de fluorose dentária em escolares de Brasília - Distrito Federal. Rev Odontol Univ São Paulo 1998; 12(3): 225-30.

5- Cury JA. Dental caries and dentifrices. Cárie e creme dental Jornal ABOPREV 1998; 9(especial).

6- Cypriano S, Pecharki GD, Souza MLR, Wada RS. Oral health of schoolchildren residing in areas with or without water fluoridation in Sorocaba, São Paulo State, Brazil. A saúde bucal de escolares residentes em locais com ou sem fluoretação nas águas de abastecimento público na região de Sorocaba, São Paulo, Brasil. Cad Saúde Pública 2003; 19(4):1063-71.

7- Dean HT. The investigation of physiological effects by the epidemiological method. In: Moulton FR, ed. Fluorine and dental Health. Washington: American Association for the advancement of Science; 1942.

8- Ermis RB, Koray F, Akdeniz G. Dental caries and fluorosis in lowand high-fluoride areas in Turkey. Quintessence Int 2003;34(5):35460 .

9- Fejerskov O, Baelum V, Manji F, Moller IJ. Fluorose dentária. São Paulo: Editora Santos; 1994

10- Freire MCM, Pereira MF, Batista SMO, Borges MRS, Barbosa MI, Rosa AGF. Prevalence of dental caries and treatment needs in 6 to 12 year-old schoolchildren at public schools. Prevalência de cárie e necessidades de tratamento em escolares de 6 a 12 anos da rede pública de ensino. Rev Saúde Pública 1999; 33(4):385-90.

11- Geisel E, Machado PA. (1974): Lei n ${ }^{\circ} 6050$ de 24 de maio de 1974. Disponível na Internet. http://www.saude.gov.br/sps/ areastecnicas/Bucal/inicial.htm

12- Glass RL. The first international conference on the declining prevalence of dental caries. J Dent Res 1982; 61(Spec Iss):1301-83.

13- Hoffmann RHS, Cypriano S, Souza MLR et al. Dental caries experience in children at public and private schools from a city with fluoridated water. Experiência de cárie dentária em crianças de escolas públicas e privadas de um município com água fluoretada. Cad Saúde Pública 2004; 20(2):522-8.

14- Horowitz HS. Index of measuring dental fluorosis. J Public Health Dent 1986; 46(4):179-83.

15- Marcenes W, Bönecher MJS. Aspectos Epidemiológicos e sociais das doenças bucais. In: Buish YP. Promoção de saúde bucal na clínica odontológica. São Paulo: Editora Artes Médicas; 2000. p.75-81.

16- Mendonça LL, Kirchner UL, Costa RN et al. Multicenter study of dental fluorosis and dental caries in 7 and 10-year-old schoolchildren of Belo Horizonte - Part 1. Estudo multicentro da fluorose dental e cárie dental em escolares de 7 e 10 anos de Belo Horizonte - Parte 1. RPG1998;5(2):101-7. 
17- Monroy OV, Hermosillo HV, Camacho MEI et al. Cambios en la prevalencia de la caries dental en escolares de tres regiones de México: encuestas de 1987-1988 y de 1997-1998. Rev Panam Salud Publica 2003;13(5):320-6.

18- Moreira B-HM, Pereira AC, Oliveira SP. Evaluation of the prevalence of dental caries in schoolchildren in urban area of Southeastern Brazil. Avaliação da prevalência de cárie dentária em escolares de localidade urbana da região sudeste do Brasil Rev Saúde Pública 1996;30(3):280-4.

19- Moysés SJ, Moysés ST, Allegretto ACV et al. Dental fluorosis: epidemiological fiction? Fluorose dental: ficção epidemiológica? Rev Panam Salud Publica 2002; 12(5):339-46.

20- Renson GE, Crilaers PJA, Ibunkle SAJ et al. Changing patterns of oral health and implications for oral health manpower. Int Dent J 1985;1:81-7.

21- Riordan PJ, Banks JA. Dental fluorosis and fluoride exposure in Western Australia. J Dent Res 1991; 70 (7):1022-8.

22- Sëppa L. The future of preventive programs in countries with different systems for dental care. Caries Res 2001; 35(suppl 1):269.

23- WHO. Oral health surveys, basic methods. 4 ed. Geneva: World Health Organization, 1997 